\title{
雜錄
}

\section{臺灣南湖大山山頂附近に産する擬擦痕碟 〔早坂一郎〕}

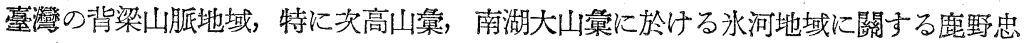
雄，田中蹕兩理學士の調查報文は臺灣地質の研究者にとつてのみならず，一般に地質 學並びに地史學などに關心を有つ者にとつて極めて貴い資料である。

その內で田中, 鹿野兩氏共著「臺灣南湖大山山晕に於ける水蝕地形」(地理學評論 $\mathrm{x}$,

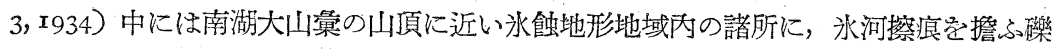
や岩盤上の䂰磨面などの發見されたことが記述されてある。特に立派な數個の寫椇も 揭げられてるるので，夫等についての記載が必ずしも充分とは思はれないが，兩氏の 論旨に對するそれ等の意義は充分に理解される。

この小文の目的とするところは，同じ南湖大山の山項附近に媫數に散布してるると 林朝留理學士が觀察し，且持ら歸つたところの擬擦痕礫の標本の紹介に過ぎない。林 理學士は本年の夏或仕事の営の出張のついでに，南湖大山の山頂附近を稍詳しく觀察 する機會を得たのであるが，其際氷河地形，氷河遺跡等で近頃特に著名になつた地域 であることに留意して，地形並びに一般水蝕現象についての資料を蒐めることに努め たのである。

林理學士の調査の結果についで, 私は口頭を以て說明を聞き，且標本の提示を受け たのでめるが，ここには其說明の要點量記すに止める。（詳しいことはいづれ林氏が 目下の出張先から歸つた上で，改めて報告する必要を生ずるか子知れない）。郎台林 氏は南湖大山の三角點の下の附近で氷蝕礫の標本穵得しものと大いに探し求めたので めつたが，不幸にしてェ 個も得られなかつた。而して其らしいもので見付かつたのは， ここに寫蕒に示した樣なものばかりであり，而も其數は相當に多いと云ふ。

其標本が如何なるものであるかは，ここに揭げた寫真からも直ちに判るであら5が 念の為簡單に記載する。標本は薄い黑色粘板岩の lamellae をはさむ灰褐色の堅い石 英質板爿砂岩の一片で，細い石英脈に貫かれてるる。其兩面にはこの黑色で幾分滗靑 質に見える粘板岩の薄層が附着してるる。其面の上に殆ど直線的な，一見氷河條廈と 思はれる多數の線がある。之等の線の內には方向の違つたすのう出つて，互に䄄交つ 


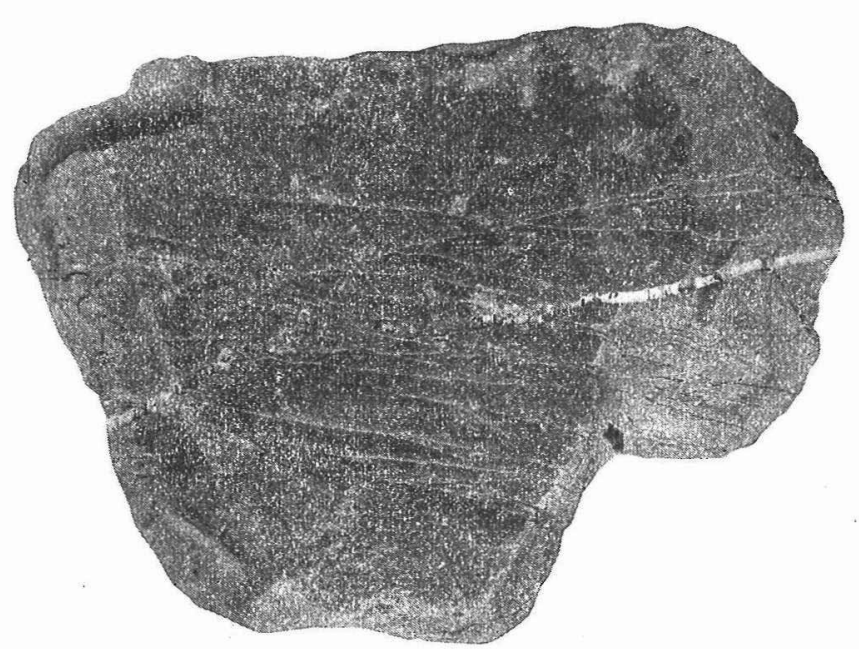

第 $\mathrm{I}$ 圖

てるる. 第 $x$ 圆はこの標本の寫嘪で寛物の $3 / 8$ に縮めてめるが，其厚さは $3,5 \mathrm{~cm}$ 位 のものである。粘板岩の部分の表面に見られる線は，粘板岩がはげ落ち，更に其下の 砂岩の一部がかけ落ちたところまで一續きになつてるるのみならず，この部分では此 砂岩の內部の構造がよく認められる。郎号ルーペの助究借りるまでもなく，ここに揭 げた寫真からも直らに制る樣に，この砂岩片には曆面に對して 270 度内外の角度を なす無敕の細かな節理が出來て居り，標本の表面に見らるる條痕樣の線は，實は之等 の節理が曆面と交る線に外ならない。この事實は第エ圖の右端でよく見られる。第2 圖は位置の關係上，第 $\mathrm{I}$ 圖と同じ縮尺には出來なかつたが，同じ祭本穵右端から見た 寫貝である。第エ圖を補ふだらうと思ひここに揭げて扣く。

之等の線は詳しく調べれば制る樣て，この砂岩片の表面上では極めて僅かではある が，楷段狀をなしてるる。この楷段は前述の細かな節理に沿ふて正斷層型の微細な段 違ひを生じた結果に外ならない。表面の粘枢岩の部分では其段違ひが㞗々微細な Flexure そなつてるる。斯樣な無數の小節理及び小斷㸴は大きな造山力に依る樫力などの 影響で出來たものに相逜ない。

試みに，第 I圖の周園の部分を塤ひ隱し，其中央部の黑色粘板岩の部分のみ学露は して見られよ。其の「氷河䙢痕らしさ」は一段と著しくなるであらら。特に，その多 


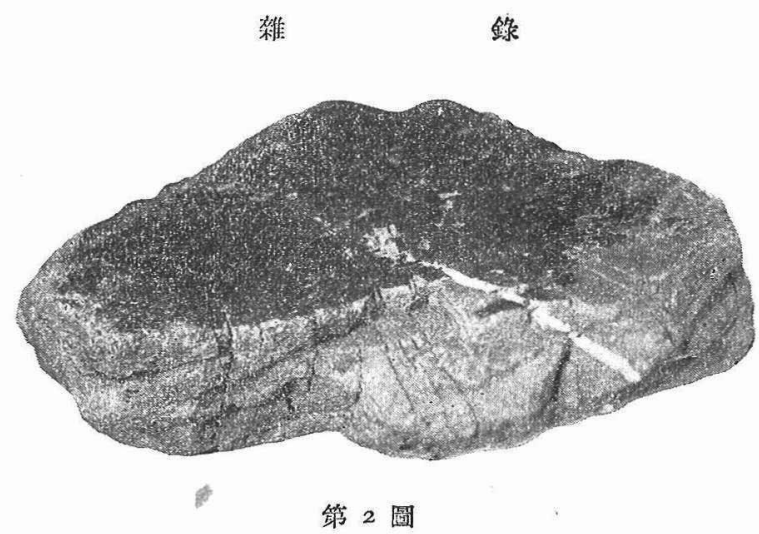

數が水河地形の地域に產するといふのでするから，礫の内部構造に注意することに氣 付かなかつたならば，林理學士も或は此標本を直に氷蝕變として持ち炜つたであらう。 ここに擬擦痕䃯の一例として報告し，氷河學者諸氏の御參考に供する次第である。

\title{
(ro月23日 臺北帝國大學地質學敉室にて)
}

\author{
Abstract \\ Boulder With Mock Striation in the Neighbourhood \\ of the Peak of Nanko-Taizan, Taiwan \\ Ichirô $\mathrm{H}_{\mathrm{AY}} \mathrm{ASAKA}_{\mathrm{A}}$
}

Sandstone slabs penetrated by numerous minute straight joints with very slight vertical displacements were recently found by $\mathrm{R}_{I N}$ quite abundantly around the peak region of Nanko-Taizan, where physiographical evidences of former glaciation seem to

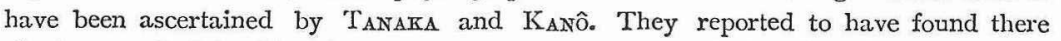
glacier-scratched boulder, for which RIN searched earnestly but in vain. The joints, or rather minute faults are represented by equally minute flexures here and there in the slate patch attached to the surface of the specimen.

\section{La Haute- Tarentaise. [P.Libert]}

Ann。 de Géogr. 43 (r934), 579-593.

Haute-Tarentaise は Alps の中心に位置し其の高度起伏と共に經濟上人文上より見て も，特殊な性質を具へた高山的色彩の濃厚な地方である。Isère 谷の水源は $2400 \mathrm{c}$ で

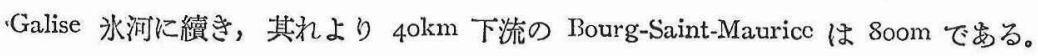

